\title{
THE AMOUNT AND NATURE OF URINARY PROTEINS IN NORMAL HUMAN SUBJECTS ${ }^{1,2}$
}

\author{
By DEMETRIOS A. RIGAS AND CARL G. HELLER \\ (From the Division of Endocrinology of the Department of Medicine, University of Oregon \\ Medical School, Portland, Oregon)
}

(Submitted for publication February 26, 1951 ; accepted May 28, 1951)

Glomerular filtrate and normal urine have generally been regarded as being protein-free. The presence of protein in the urine has long been considered as indicative of renal disease. The classical experiments of Wearn and Richards (1), demonstrating the absence of protein in the glomerular filtrate and urine of the frog, added impetus to this belief.

A number of investigators have taken issue with the generally held concept that the urine is proteinfree including Möerner (2) who found 22-78 mg. per liter, Gunton and Burton (3) who declared the mean concentration to be $3.7 \mathrm{mg}$. per cent and Addis (4) who states $10 \mathrm{mg}$. of protein per 24 hours is normally excreted. The nature and exact amount of protein in urine, however, continues to be obscure.

The application of two technics, a) concentration of the urinary proteins by ultrafiltration (5) and b) analysis of the electrophoretic migration patterns using the Tiselius apparatus, has permitted us to approach the problem of the nature and amount of the proteins contained in normal urine. Ultrafiltration of urine through a collodion membrane, as routinely applied in our laboratory to recover urinary gonadotrophins (6), permits the concentration of protein from a large volume of urine. Sufficient protein can be concentrated in this way from a 72 hour aliquot of urine to have enough to submit to electrophoretic analysis.

\section{MATERIALS AND METHODS}

Subjects consisted of 12 normal male and three normal female students 24 to 30 years old. The women collected urine during the first half of the menstrual cycle. Each subject collected the total urinary output for a 72

1 Supported generously by grants from Ayerst, McKenna and Harrison, Limited, New York, N. Y., and the Schering Corporation, Bloomfield, N. J.

2 Presented in part before the Northwest Group of the American Federation for Clinical Research, Vancouver, British Columbia, April 21, 1951. hour period. Preservatives were avoided. The urine was refrigerated immediately and kept in the refrigerator throughout the period of collection. Specimens were delivered at the end of each 24 hour collection period, immediately filtered through paper to eliminate formed elements, found to be free of gross protein by the sulfosalicylic acid test, and run through the ultrafilter. These procedures and all subsequent concentration procedures were conducted in the cold room at $0^{\circ} \mathrm{C}$. to keep denaturation at a minimum.

In order to establish that the proteins retained on the collodion membrane after ultrafiltration could be quantitatively recovered without alteration, several methods of extraction were compared, using the same pooled urine. The proteins were directly eluted from the membrane at pH 7 with a) distilled water, b) $0.14 \mathrm{M}$ saline, and c) 1.0 M saline, or $d$ ) eluted from the dry powder residue remaining after the collodion membrane had been dissolved and extracted with alcohol-ether. In the latter method the proteins were reprecipitated with 5 volumes of 95 per cent ethanol, before dissolving in veronal buffer at $\mathrm{pH} 8.6$, ionic strength 0.1 . In each method the protein solution was dialyzed against veronal buffer before being subjected to electrophoresis. Eluting the proteins directly from the membrane with distilled water gave a lowered recovery of $\gamma_{1}, \gamma_{2}$ and $\beta$ globulins, otherwise each method was identical qualitatively and quantitatively. Since desoxyribonucleoproteins are insoluble in $0.14 \mathrm{M}$ saline, the fact that identical results were obtained suggests that desoxyribonucleoproteins are not present.

The following procedure for recovering the protein collected on the membrane was therefore adopted: The membrane was placed in a $15 \mathrm{ml}$. centrifuge tube and dissolved with $15 \mathrm{ml}$. alcohol-ether (1 part absolute alcohol and 1 part anhydrous ether), centrifuged and the residue washed three times with alcohol-ether, once with anhydrous ether, dried and stored at $0^{\circ} \mathrm{C}$. After the entire 72 hour collection had been subjected to this treatment, each of the three tubes, containing residue from 24 aliquots each, was extracted three times using $2 \mathrm{ml}$. of 1.0 M saline each time. The pooled supernatant fluid was placed in a cellophane bag and dialyzed against running water $\left(4^{\circ}\right.$ C.) for 24 hours. For each $10 \mathrm{ml}$. of dialyzed supernatant, $2 \mathrm{ml}$. of saturated saline solution were added, and the proteins precipitated with 5 volumes of 95 per cent ethanol. The precipitate was recovered by centrifugation, washed with absolute alcohol and once with anhydrous ether and dried.

In order to compare the urinary proteins with those of 

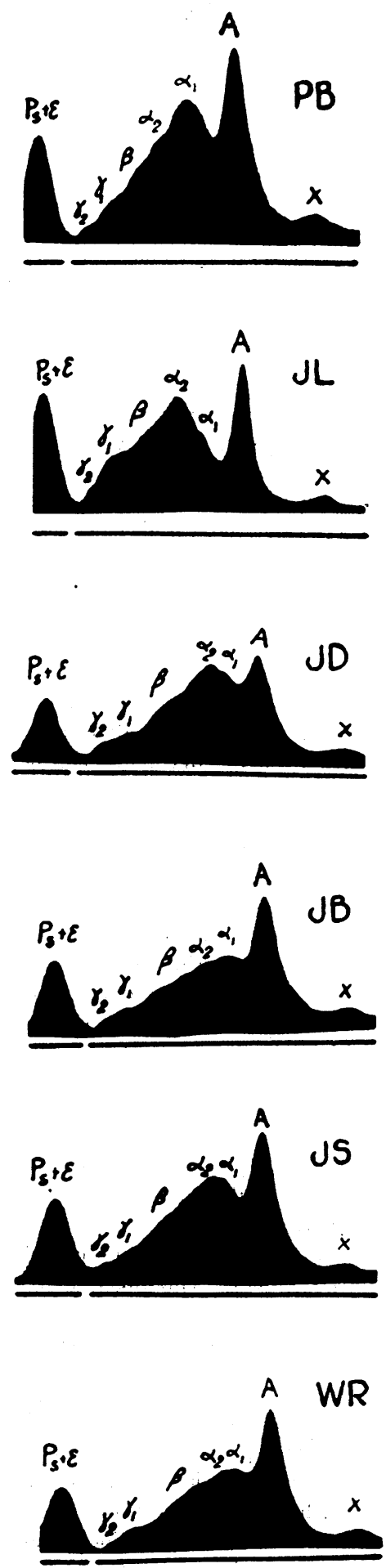
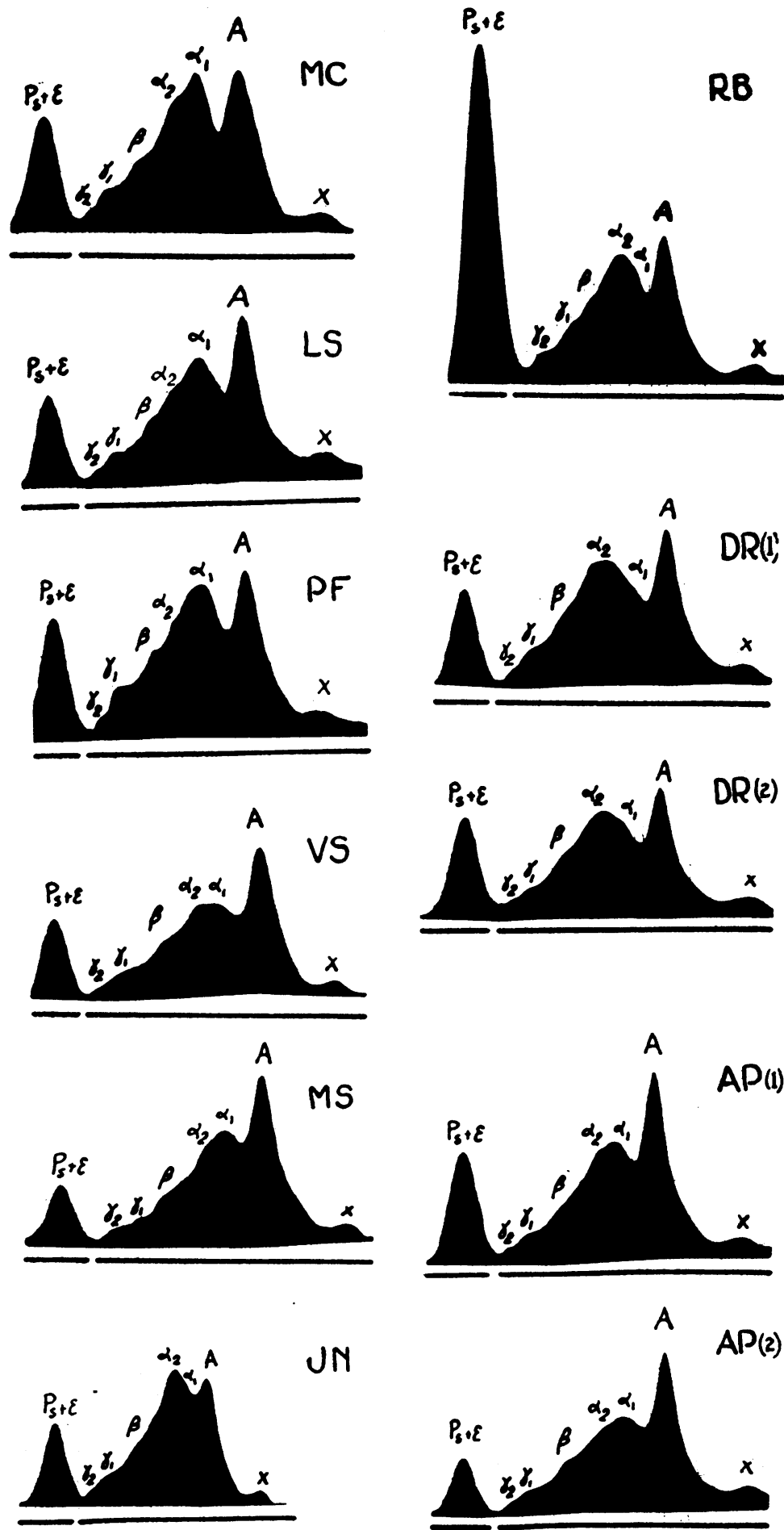

Fig. 1. Electrophoretic Migration Patterns of Urinary Proteins from Normal Subjects

Taken after 120 minutes migration in veronal buffer, $\mathrm{pH} 8.6$, ionic strength 0.1 , potential gradient 7.4 volts $/ \mathrm{cm}$. The descending limb is depicted. The pattern on patient J. N. was taken at 90 minutes. 


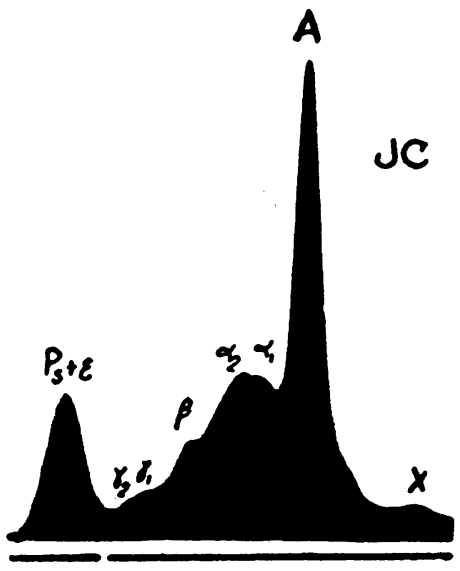

Fig. 2. Electrophoretic Migratio
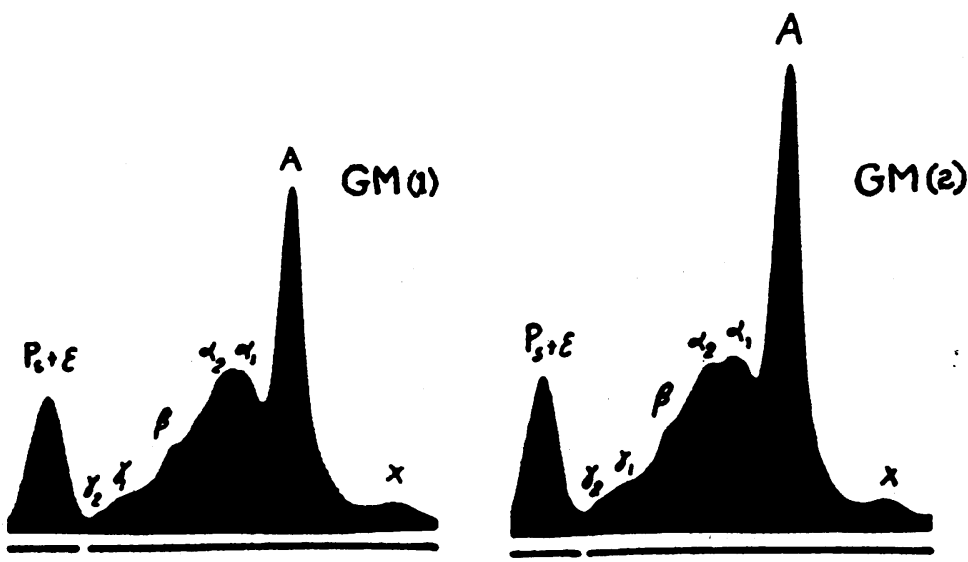

One hundred twenty minutes of migration in veronal buffer, $\mathrm{pH} 8.6$, ionic strength 0.1 , potential gradient 7.4 volts $/ \mathrm{cm}$.

the blood serum, veronal buffer at $\mathrm{pH} 8.6$, ionic strength 0.1 , was used. This had been found to give the most satisfactory resolution of the blood serum proteins (7). The dry material was dissolved in $10 \mathrm{ml}$. of this buffer and dialyzed in a cellophane tube for 24 hours against 2 liters of the same buffer, changing buffer once during dialysis. Volume changed very little during dialysis so that the solution could be used directly in our analytical cell which requires $9.8 \mathrm{ml}$. (the cell with the long middle section). The electrophoretic analyses were performed with the Klett equipment using the Longsworth's scanning method for recording the patterns. The proteins were allowed to migrate for 120 minutes under the influence of a potential gradient of 7.4 volts $/ \mathrm{cm}$., at a temperature $0.5^{\circ} \mathrm{C}$. Due to urinary pigments absorbed or held by stronger combination on the protein, infra-red

TABLE I

Four chemical tests for identification of urinary proteins in the different fractions

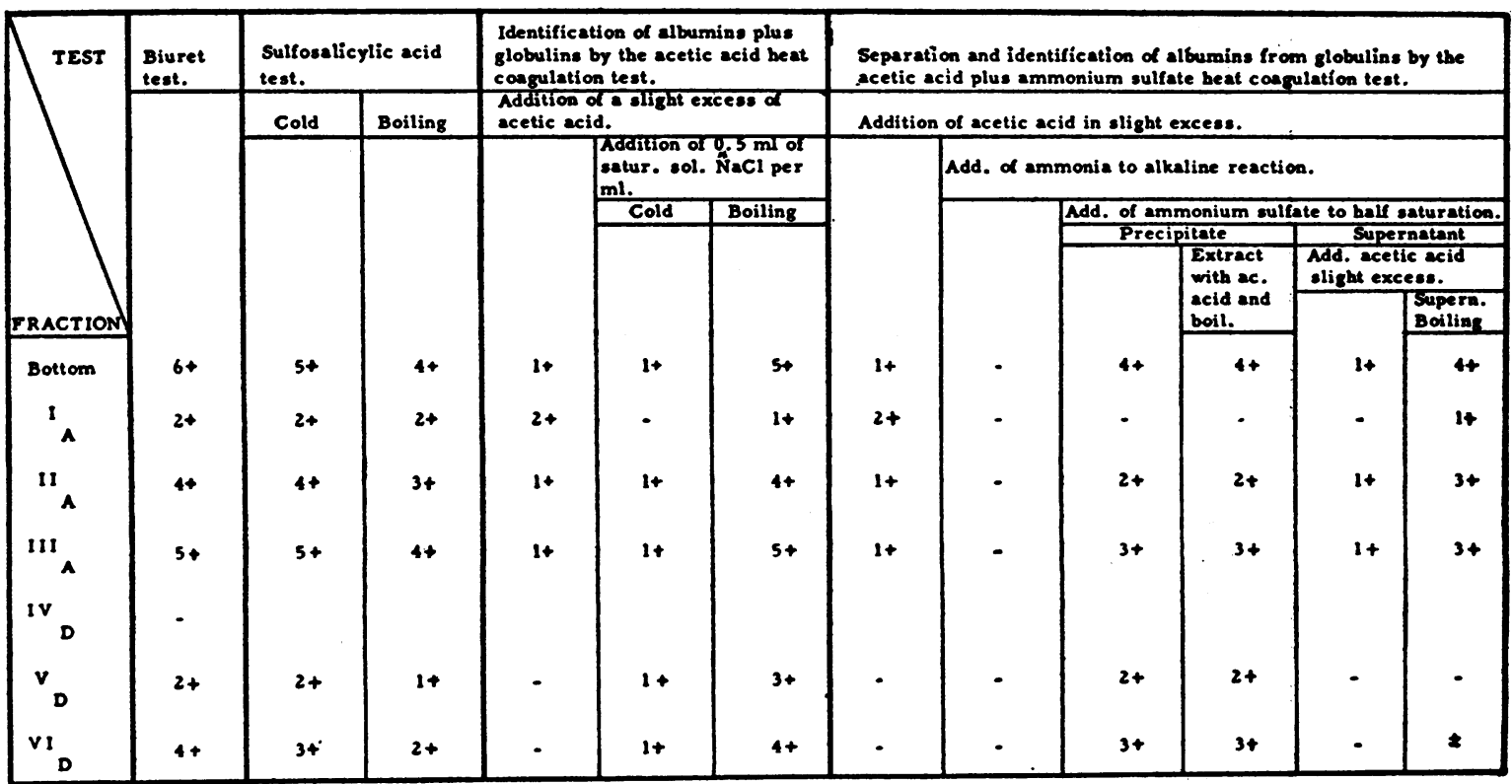

The number in front of + indicates the color density or the amount of precipitate formed after completion of all steps indicated in top of each column. Negative results are indicated as-. 
light and spectroscopic plates sensitized for the infra-red were used. Because of the low protein concentration the boundaries were recorded with a magnification factor $K^{\prime}=1 / 6$ (i.e., the ratio of the speed of the photographic plate to that of the schlieren diaphragm was twice the usual).

\section{RESULTS}

Sufficient protein was concentrated from the 72 hour urine collection of each of the 15 normal control subjects to detect several protein components in the electrophoretic analysis. The most striking result was the uniformity of the pattern elicited. Note that not only were the patterns of males similar to each other but that females were in no way different.

It is also noteworthy that, whereas minor variations exist between patterns of one individual as compared to another, the pattern of a given individual tends to remain constant over several months time. This is illustrated by normal con- trols DR (1) and (2) and AP (1) and (2) in Figure 1 and by a subject with orthostatic proteinuria, GM (1) and (2) in Figure 2.

It was possible to calculate the total urinary protein output from the electrophoretic analyses. A mean value of $39.0 \mathrm{mg} . / 24$ hours was found. The extremes were $30.5 \mathrm{mg}$. and $49.6 \mathrm{mg}$.

It was further noted that whereas the relative amounts of protein excreted by the same individual remained constant, as judged by the electrophoretic patterns, the total output varied considerably from time to time. From Table II it can be seen that DR, whose pattern remained constant, excreted $35.5 \mathrm{mg}$. on one occasion and 43.9 mg. on another occasion some months later.

\section{Analysis of the electrophoretic patterns}

False boundaries represent buffer ion concentration differences existing between the protein and

TABLE II

\begin{tabular}{|c|c|c|c|c|c|}
\hline \multicolumn{6}{|c|}{$\begin{array}{l}\text { Amount of protein, albumin and globulin contained in urine } \\
\text { of normal male and female subjects and in orthostatic albuminuria }\end{array}$} \\
\hline Subject & Sex & $\begin{array}{c}\text { Total } \\
\text { Protein } \\
\text { mg./24hrs }\end{array}$ & $\begin{array}{l}\text { Albumin } \\
\text { mg./24hrs }\end{array}$ & $\begin{array}{l}\text { Globulins } \\
\text { mg./24hrs }\end{array}$ & $\begin{array}{l}\text { A/G } \\
\text { Ratio }\end{array}$ \\
\hline $\begin{array}{l}\text { PF } \\
\text { LS } \\
\text { PB } \\
\text { JL } \\
\text { MC } \\
\text { JB } \\
\text { JS } \\
\text { WR } \\
\text { JD } \\
\text { RB } \\
\text { DR (1) } \\
\text { DR (2) } \\
\text { AP (1) } \\
\text { AP (2) } \\
\text { VS } \\
\text { MS } \\
\text { JN } \\
\text { Average } \\
\text { Standard } \\
\text { Deviation }\end{array}$ & $\begin{array}{c}\text { Male } \\
\text { " } \\
\text { " } \\
\text { " } \\
\text { " } \\
\text { " } \\
\text { " } \\
\text { " } \\
\text { " } \\
\text { " } \\
\text { " } \\
\text { Female } \\
\text { " } \\
\text { " }\end{array}$ & $\begin{array}{l}46.3 \\
41.8 \\
43.7 \\
38.2 \\
49.6 \\
31.2 \\
38.1 \\
31.0 \\
32.8 \\
39.4 \\
35.5 \\
43.9 \\
44.0 \\
42.1 \\
38.3 \\
41.2 \\
30.5 \\
39.0 \\
5.7\end{array}$ & $\begin{array}{l}14.1 \\
14.1 \\
16.1 \\
10.6 \\
17.1 \\
11.8 \\
13.5 \\
11.2 \\
10.6 \\
12.6 \\
12.1 \\
13.1 \\
15.3 \\
15.7 \\
14.6 \\
14.6 \\
9.0 \\
14.8 \\
2.2\end{array}$ & $\begin{array}{l}32.2 \\
27.7 \\
27.6 \\
27.6 \\
32.5 \\
19.4 \\
24.6 \\
19.8 \\
22.2 \\
26.8 \\
23.4 \\
30.8 \\
28.7 \\
26.4 \\
23.7 \\
26.6 \\
21.5 \\
25.8 \\
3.9\end{array}$ & $\begin{array}{l}0.44 \\
0.51 \\
0.58 \\
0.38 \\
0.52 \\
0.60 \\
0.55 \\
0.56 \\
0.48 \\
0.47 \\
0.51 \\
0.43 \\
0.53 \\
0.59 \\
0.61 \\
0.55 \\
0.42 \\
0.51\end{array}$ \\
\hline \multicolumn{6}{|c|}{ Cases having "orthostatic albuminuria" } \\
\hline $\begin{array}{l}\text { JC } \\
\text { GM (1) } \\
\text { GM (2) }\end{array}$ & $\begin{array}{c}\text { Male } \\
\text { " } \\
\text { " }\end{array}$ & $\begin{array}{l}52.7 \\
49.4 \\
51.0\end{array}$ & $\begin{array}{l}28.8 \\
21.8 \\
29.4\end{array}$ & $\begin{array}{l}23.9 \\
27.6 \\
21.6\end{array}$ & $\begin{array}{l}1.20 \\
0.79 \\
1.36\end{array}$ \\
\hline
\end{tabular}




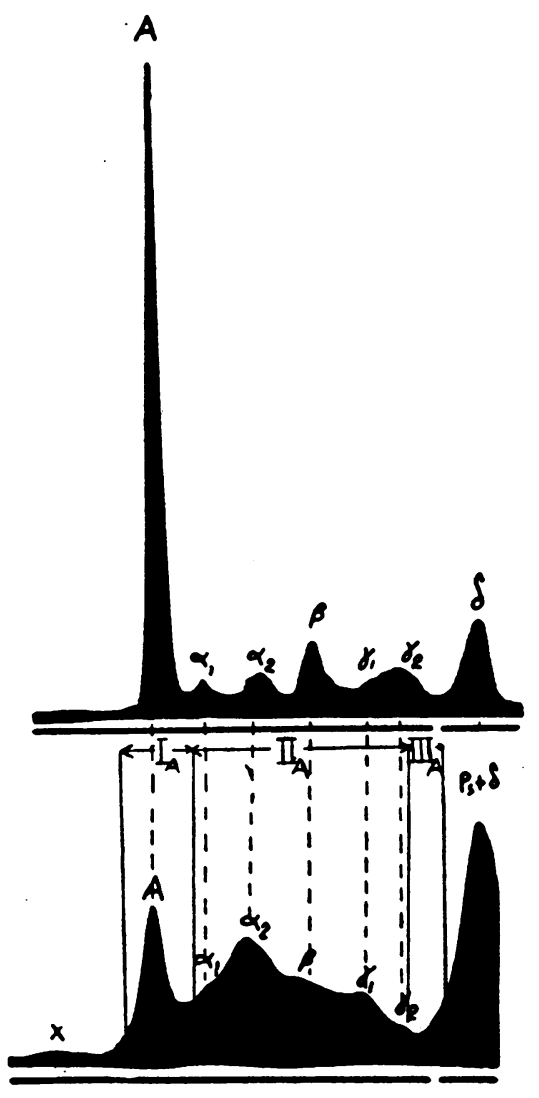

Ascending

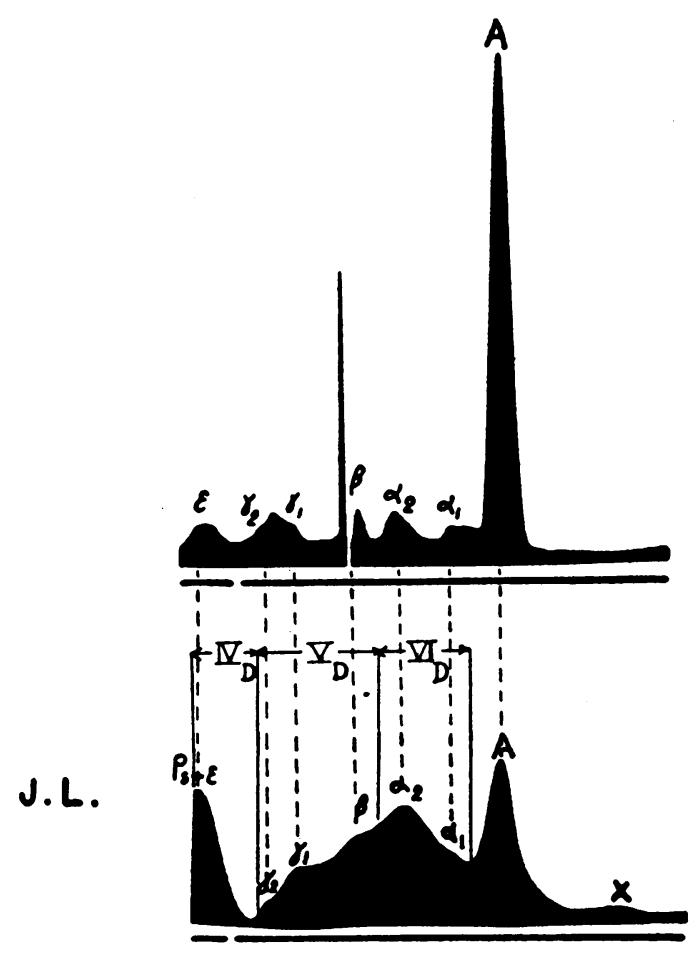

Descending

Fig. 3. Comparison of Electrophoretic Patterns of Normal Human Serum and Urinary Proteins

Taken after 150 minutes-migration in veronal buffer, $\mathrm{pH} 8.6$, ionic strength 0.1 , potential gradient 7.4 volts $/ \mathrm{cm}$. Patterns for serum are above, urine below.

buffer solutions. These are conventionally designated as $\epsilon$ for the descending limb and $\delta$ for the ascending limb. A larger false boundary than occurs in serum was noted in the patterns from the urinary concentrates. This was found to be due to a high molecular weight polysaccharide and therefore the false boundaries are designated as $\mathrm{Ps}+\epsilon$ and Ps + $\delta$, respectively.

The initial position of the boundaries is designated in the patterns by a break in the horizontal black line below each pattern.

Comparisons of urinary with serum patterns reveals the same components in each. This can be seen in both the ascending and descending limbs in Figure 3 after both serum protein and urinary proteins have migrated for 150 minutes under similar experimental conditions. The serum pattern was recorded at conventional speed of the photographic plates and the urinary pattern at double speed. The heights of the urinary peaks are consequently doubled.

It is striking that for each serum protein component represented in the pattern as a peak, a corresponding urinary component can be identified as having migrated the same distance in the same length of time under identical circumstances. Corresponding components have been designated by the identical label, i.e., $\alpha_{1}, \alpha_{2}, \beta$, $\gamma_{1}, \gamma_{2}$ globulins and A, albumin (Figure 3), and to facilitate comparisons dotted lines have been drawn between corresponding components.

It is concluded that proteins having the same ranges of mobilities exist in normal human blood serum and in normal human urine. 
Although qualitatively each serum protein appears to be represented in the urine, by a protein of similar mobility, the relative amounts of each protein in the urine varies considerably from that in serum. It is at once apparent that urine contains relatively more globulin than serum and relatively less albumin than serum. Thus the $A / G$ ratio for urine is the reverse of that existing in serum.

The globulin components vary as well. In normal serum the $\beta$ and $\gamma_{2}$ globulins predominate, while in normal urine the components labelled $\alpha_{1}$ and $\alpha_{2}$ globulins predominate. The urinary globu- lins are less homogeneous than the serum globulins. The heterogeneity may have been acquired during the ultrafiltration process or could be due to the coexistence of proteins with intermediate electrophoretic mobilities, which are either absent from serum, or present in very small amounts.

A component not found in serum but uniformly found in urine migrating more rapidly than albu$\min (\mathrm{A})$ is designated as $\mathrm{X}$ in the patterns.

The chemical behavior of urinary proteins separated by migration in the Tiselius apparatus. It would be a remarkable coincidence if totally different urinary proteins or even non-proteins mi-
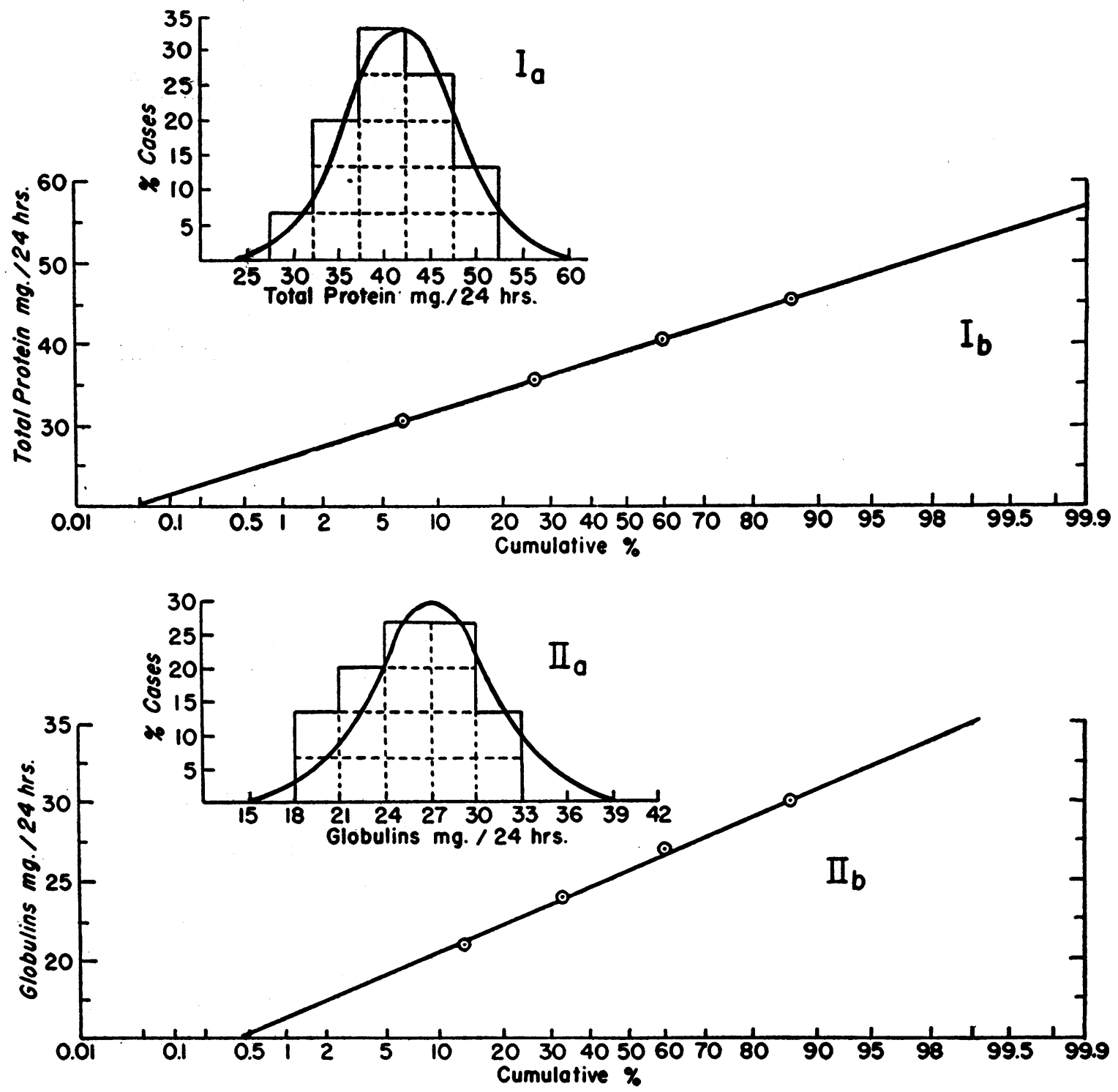

(FIG. 4.-Continued on next page) 


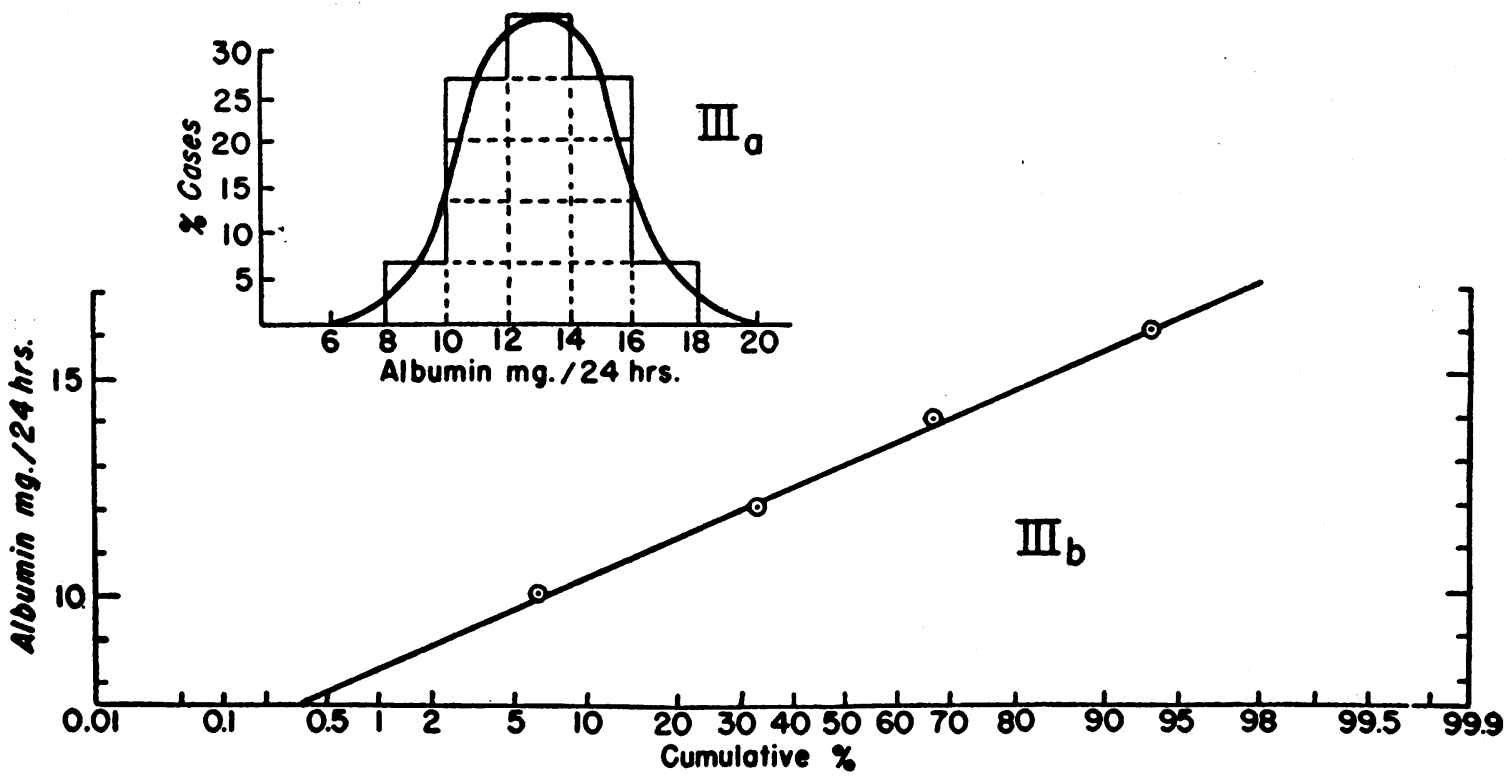

Fig. 4.-Contimued. Statistical Distribution Curves and Probability Lines Showing Gaussian Distribution of the Amount of Total Protein, Albumin and Globulin in Urine of Normal Subjects

grated at the same speed as each of the serum proteins. Nonetheless, to exclude this possibility various fractions of the proteins were withdrawn from the electrophoresis cell at the end of 150 minutes of migration. This was possible after devising an instrument capable of accurately withdrawing a fraction of protein from the electrophoretic cell (8). This consisted of a motor-driven syringe attached to a needle long enough to reach any migrating component in the cell. Liquid was withdrawn slowly enough to prevent turbulence.

The fractions thus obtained are indicated in Figure 3 by the solid black vertical lines and designated as fractions $I_{\mathbf{A}}, \mathrm{II}_{\mathbf{\Lambda}}$, and $\mathrm{III}_{\mathbf{A}}$, for the ascending limb and fractions $I_{D}, V_{D}$, and $V_{D}$, for the descending limb. Thus each fraction encompassed the following components :

$\mathrm{I}_{\mathbf{A}}$-Albumin A plus component $\mathrm{X}$.

$\mathrm{II}_{\Lambda}-$ Albumin A plus $\alpha_{1}, \alpha_{2}, \beta, \gamma_{1}$, and some $\gamma_{2}$ globulin.

III $_{\mathbf{\Delta}}-$ Mixture of all protein components plus $\mathrm{X}$ but excluding false boundary $\mathrm{P}_{\mathrm{s}}+\delta$.

$I V_{D}$-false boundary $\mathrm{P}_{\mathrm{s}}+\epsilon$.

$V_{D}$-false boundary plus $\gamma_{2}, \gamma_{1}, \beta$ and some $\alpha_{2}$ globulin.

$\mathrm{VI}_{D}$-mixture of all components including false boundary but excluding albumin $\mathrm{A}$ and component $\mathrm{X}$.
"Bottom fraction"-mixture containing all original components taken from bottom cell.

Each fraction was dialyzed in running water until free from buffer salts and then subjected to the various tests for proteins indicated in Table $I$, with the exception of fraction $\operatorname{IV}_{\mathbf{D}}$ which proved to be devoid of protein by the Biuret test.

All other fractions proved to contain protein. Fraction $I_{\mathbf{\Delta}}$ was positive for all tests in which albumin elicits a precipitate and negative to tests in which globulin alone elicits a precipitate. In addition the test for mucoprotein was positive. Since fraction $I_{\Delta}$ contained not only component A (albumin) but also component $\mathrm{X}$, the reaction for mucoprotein may have been due to the presence of component $\mathrm{X}$.

The remaining fractions were presumed to contain globulin and tested positively in each test in which globulins elicit a precipitate.

Fractions $V_{D}$ and $V_{D}$, presumed to contain globulin but not albumin, failed to react to a test in which albumin alone elicits a precipitate. These two fractions were devoid of reaction to tests which elicit a positive reaction for acid precipitable mucoproteins, but the sulfosalicylic acid test revealed that glycoproteins and acid soluble mucoproteins were also present. Since they contained neither component $\mathrm{A}$ nor $\mathrm{X}$, it may be presumed that acid 
precipitable mucoproteins were contained in one or the other of the latter fractions only.

None of the fractions contained desoxyribonucleoproteins since they were soluble in $0.14 \mathrm{M}$ $\mathrm{NaCl}$, vide supra. From phosphorus analysis it seemed unlikely that any nucleoproteins were present since it was calculated that approximately one phosphorus atom per protein molecule was present and if nucleoproteins were present to any extent more phosphorus would of necessity be detected.

Fraction $I_{D}$ (containing the false boundary only) while not a protein, proved to contain a nondialyzable substance which could be precipitated with 5 volumes of 95 per cent ethanol. It gave a dark brown color when mixed with concentrated sulfuric acid, and a positive Molisch reaction, which characterized it as a polysaccharide.

Quantitative analysis. Since the urinary concentrates contain polysaccharides in addition to the protein, dry weight will not yield information as to the total amount of protein in the urine. Such information was yielded by measuring the area of the electrophoretic pattern produced by protein components as a whole, and albumin and globulin separately, then applying the formula:

$$
\text { Concentration }=\frac{\mathrm{K}^{\prime}}{\mathrm{K} \cdot \mathrm{a} \cdot \mathrm{b}} \cdot \mathrm{A} \text {, }
$$

where $K^{\prime}=1 / 6$, $a$ and $b$ are constants of the apparatus and $\mathrm{A}$ is the measured area. $\mathrm{K}$ is the refractive index increment taken as $\mathrm{K}=0.001858$ (9) which is the value for human serum albumin corrected for the wave length $\lambda=7200 \AA$ of the light used, according to the formula :

$$
K_{\lambda}=K_{5780 \AA}\left(0.940+2.00 \times 10^{6} / \lambda^{2}\right) .
$$

The values for total protein, albumin, globulin and $A / G$ ratio are recorded in Table II. When subjected to statistical analysis it was found that each follows a normal distribution curve as seen from Figure 4. The total protein excreted per 24 hours thus has a mean value of $39.0 \mathrm{mg}$. and a standard deviation (estimated from the formula $\sigma=\sqrt{\frac{\Sigma \Delta^{2} \cdot N}{N-1}}$ ) of $5.7 \mathrm{mg}$. For globulins the mean is $25.8 \mathrm{mg} . / 24$ hours, and standard deviation $3.9 \mathrm{mg}$. For albumin the mean is $14.8 \mathrm{mg} . / 24$ hours, and standard deviation $2.2 \mathrm{mg}$. The average $A / G$ ratio is 0.51 as contrasted to the $A / G$ ratio for normal serum of 1.15 .
Two individuals (J. C. and G. M.) who were initially included with the normal control series exhibited patterns inconsistent with the remainder of the series. Albumin excretion was distinctly higher (falling out of the normal range, according to the Chavenet probability criterion), total proteins were elevated, but the proportion of the different globulin components were not at variance with the normal subjects (Figure 2). On closer questioning it was revealed that the clinical diagnosis of orthostatic albuminuria had been made on G. M. and although no such clinical diagnosis had been made on J. C., two siblings had the clinical diagnosis of orthostatic albuminuria. These cases are excluded from the distribution charts and listed separately in Table II.

\section{DISCUSSION}

The source of the urinary protein remains unclear. Experimental evidence exists to suggest that the renal tubules do not excrete protein but in fact tend to absorb protein when present. After producing renal damage Bieter (10) found that glomerular fish developed proteinuria whereas aglomerular fish did not. The reabsorption of proteins by tubules was demonstrated by Gerard (11) upon introducing several colloidal substances of different molecular weight into the proximal end of the proximal convoluted tubule of the salamander. He noted that the greater the molecular weight of the substance injected, the more distally it was absorbed. Dock (12), Gilson (13), Smetana $(14,15)$, and Oliver (16) concluded that protein is excreted by the glomerulus and absorbed by the tubules after injecting Evans blue dye (which combines with albumin) and other protein-bound dyes into rats.

Since proteins dyed with foreign substances might alter the permeability of the glomerular membrane, Addis (17) gave injections of rat serum to rats of the same strain and was able to produce proteinuria without producing renal damage. He ascribed the proteinuria to the raised protein concentration of the plasma. Similar observations have been made on dogs receiving injections of dog plasma (18) and in patients with liver cirrhosis after repeated intravenous injections of human serum albumin (19). This indirect evidence suggests that the proteins we detected in 
urine are the result of glomerular filtration. The greater proportion of globulin in the urine may be due to greater tubular reabsorption of albumin.

\section{SUM MARY}

The quantity and nature of proteins in the urine of normal adults have been determined by applying the ultrafiltration concentration technic and electrophoretic migration analysis.

Components having the same electrophoretic mobility as those in normal serum were discovered to exist in normal urine, namely albumin, $\alpha_{1}, \alpha_{2}, \beta$, $\gamma_{1}$, and $\gamma_{2}$ globulin. The relative amounts of each differ for urine and sera in that the $A / G$ ratio is reversed for urine. Whereas $\beta$ and $\gamma_{2}$ globulins predominate in sera, the predominant globulins migrate with the same mobility as $\alpha_{1}$ and $\alpha_{2}$ globulins.

The mean normal excretion of protein is 39.0 mg./24 hours, for albumin $14.8 \mathrm{mg} . / 24$ hours and for globulin $25.8 \mathrm{mg} . / 24$ hours. The average $\mathrm{A} / \mathrm{G}$ ratio is 0.51 .

Mucoproteins and glycoproteins, as well as a polysaccharide and an unidentified component $\mathrm{X}$, were found to be present in normal urine.

A technic is described for withdrawing various fractions of proteins from the electrophoretic cell after migration has occurred. Chemical analysis of the fractions confirmed that both albumins and globulins are excreted.

\section{REFERENCES}

1. Wearn, J. T., and Richards, A. N., Observations on the composition of glomerular urine, with particular reference to the problem of reabsorption in the renal tubules. Am. J. Physiol., 1924-25, 71, 209.

2. Möerner, K. A. H., Untersuchungen über die Protëinstoffe und die eiweissfällenden Substanzen des normalen Menschenharns. Skandinav. Arch. f. Physiol., 1895, 6, 332.

3. Gunton, R., and Burton, A. C., On the concentration of protein in samples of normal urine measured by its surface activity. J. Clin. Invest., 1947, 26, 892.

4. Addis, T., The renal lesion in Bright's disease. Harvey Lectures, 1927-28, 23, 222.

5. Gorbman, A., Ultrafiltration of urine for collection and biological assay of excreted hypophyseal hormones. Endocrinology, 1945, 37, 177.

6. Jungck, E. C., Maddock, W. O., and Heller, C. G., Gonadotropic hormone: comparison of ultrafiltration and alcohol-precipitation methods of recovery from urine. J. Clin. Endocrinol., 1947, 7, 1.

7. Longsworth, L. G., Recent advances in the study of proteins by electrophoresis. Chem. Reviews, 1942, 30, 323.

8. Rigas, D. A., Maupin, T., and Heller, C. G., A mechanical device for preparative electrophoresis. J. Lab. \& Clin. Med., to be published.

9. Perlmann, G. E., and Longsworth, L. G., The specific refractive increment of some purified proteins. J. Am. Chem. Soc., 1948, 70, 2719.

10. Bieter, R. N., Albuminuria in glomerular and aglomerular fish. J. Pharmacol. \& Exper. Therap., 1931, 43, 407.

11. Gerard, P., Comparative histophysiology of the vertebrate nephron. J. Anat., 1936, 70, 354.

12. Dock, W., Proteinuria and the associated renal changes. New England J. Med., 1942, 227, 633.

13. Gilson, B. S., Studies on proteinuria in the rat. Proc. Soc. Exper. Biol. \& Med., 1949, 72, 608.

14. Smetana, H., Permeability of renal glomeruli of several mammalian species to labeled proteins. Am. J. Path., 1947, 23, 255.

15. Smetana, H., and Johnson, F. R., The origin of colloid and lipoid droplets in the epithelial cells of the renal tubules. Am. J. Path., 1942, 18, 1029.

16. Oliver, J., The structure of the metabolic process in the nephron. J. Mt. Sinai Hosp., 1948, 15, 175.

17. Addis, T., The mechanism of proteinuria. Proc. Nat. Acad. Sc., 1949, 35, 194.

18. Terry, R., Hawkins, D. R., Church, E. H., and Whipple, G. H., Proteinuria related to hyperproteinemia in dogs following plasma given parenterally. A renal threshold for plasma proteins. J. Exper. Med., 1948, 87, 561.

19. Thorn, G. W., Armstrong, S. H., Jr., and Davenport, V. D., Chemical, clinical, and immunological studies on the products of human plasma fractionation. XXXI. The use of salt-poor concentrated human serum albumin solution in the treatment of hepatic cirrhosis. J. Clin. Invest., 1946, 25, 304. 